\title{
Effect of green-belly stink bug, Dichelops furcatus (F.) on wheat yield and development
}

\author{
Antônio R. Panizzi ${ }^{\text {a, }}{ }^{*}$, Alice Agostinetto ${ }^{b}$, Tiago Lucini ${ }^{c}$, Paulo R.V. da S. Pereira a \\ ${ }^{a}$ Embrapa Wheat, P.O. Box 3081, Passo Fundo, RS, 99001-970, Brazil \\ ${ }^{\mathrm{b}}$ Agronomy School, University of Passo Fundo, Passo Fundo, RS, 99052-900, Brazil

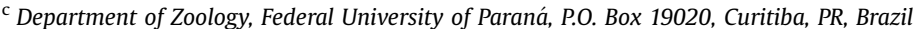

\section{A R T I C L E I N F O}

\section{Article history:}

Received 2 June 2015

Received in revised form

4 October 2015

Accepted 6 October 2015

Available online 20 October 2015

\section{Keywords:}

Pentatomidae

Damage

Yield

Wheat

Neotropics

\begin{abstract}
A B S T R A C T
The green belly stink bug, Dichelops furcatus (F.) (Hemiptera: Heteroptera: Pentatomidae) is a pest of corn and soybean in southern Brazil. It also occurs on wheat, but information on its damage to this crop is limited. To determine the need for sustainable IPM programs, the impact of this bug on wheat production should be determined. Studies were conducted in the screenhouse with 1,2 and 4 bugs caged for 16 days on single plants, cv. 'BRS Parrudo'. During the vegetative period (plants ca. $25 \mathrm{~cm}$ tall), all infestation levels significantly reduced plant height and ear head length, but did not reduce grain yield. Feeding damage caused tissue necrosis on leaves. During the booting stage, grain yield was significantly reduced with 2 and 4 bugs per plant; ear heads were small, discolored and abnormally developed. In 2013 and 2014 field trials, plants were infested for 18 days with 2, 4 and 8 bugs per $\mathrm{m}^{2}$ at vegetative, booting, and milky grain stage. At these infestation levels, there was no significant reduction in grain yield. There was a significant decrease in the number of normal seedlings resulting from seeds exposed to 8 bugs per $\mathrm{m}^{2}$ at the milky grain stage. Results suggest that, in general, there is no need to control $D$. furcatus on wheat, unless numbers are $\geq 8$ bugs per $\mathrm{m}^{2}$ during reproductive period.
\end{abstract}

(๑) 2015 Elsevier Ltd. All rights reserved.

\section{Introduction}

The green belly stink bug, Dichelops furcatus (F.) is a Neotropical pentatomid often recorded in the southern states of Brazil (Chiaradia et al., 2011; Pereira et al., 2013). This polyphagous stink bug has been registered on 27 plant species belonging to 11 plant families, which include cultivated and non-cultivated plants (Smaniotto and Panizzi, 2015). Among the cultivated plants, D. furcatus has been reported on soybean, Glycine max (L.) Merrill (Fabaceae) (Panizzi et al., 1977), sunflower, Helianthus annuus L. (Frota and Santos, 2007), corn, Zea mays (L.) (Poaceae) (Roza-Gomes et al., 2011), common oat, Avena sativa L. and on wheat, Triticum aestivum L. (Poaceae) (Chocorosqui and Panizzi, 2004; Pereira et al., 2013).

Species of Dichelops [D. furcatus and Dichelops melacanthus (Dallas)] are known to cause significant damage to wheat and corn (Chocorosqui and Panizzi, 2004; Manfredi-Coimbra et al., 2005;

\footnotetext{
* Corresponding author

E-mail address: antonio.panizzi@embrapa.br (A.R. Panizzi).
}

Roza-Gomes et al., 2011). This has resulted in the recommendation to growers of chemical control by spraying insecticides on the foliage or by seed treatment to prevent the stink bugs damage to these crops (Chocorosqui and Panizzi, 2004; Martins et al., 2009; Ávila and Duarte, 2012).

A dramatic increase in $D$. furcatus abundance in southern Brazil has been attributed to the wide adoption of the no-tillage cultivation system. This system provides food (i.e., fallen seeds of the previous crop) as well as protection (shelter underneath crop residues) during colder months (Chocorosqui and Panizzi, 2004). As temperature rises the bugs move out and feeds on wheat. Because of these field observations, and because of lack of information, studies were conducted on the effect of $D$. furcatus on yield and development of wheat plants.

In this article we report the results of screenhouse and field tests carried out to evaluate the impact of $D$. furcatus on plant height, ear head length, grain yield, and seed quality of wheat plants infested at different phenological stages of development, i.e., during early plant development (tillering), during booting, and during the milky stage of grain formation. 


\section{Materials and methods}

\subsection{Stink bug colony in the laboratory}

During May to November 2013, a colony of D. furcatus was established in the laboratory from field-collected adults obtained from crop residues and weed plants in areas previously cultivated with soybean and wheat at the Embrapa Wheat Field Experiment Station at Passo Fundo, RS, Brazil (28 $8^{\circ} 15^{\prime} \mathrm{S}$ latitude; $52^{\circ} 24^{\prime} \mathrm{W}$ longitude).

Adults were taken to the laboratory and placed in clear plastic rearing boxes $(25 \times 20 \times 20 \mathrm{~cm})$, lined with filter paper and provided with pods of green bean, Phaseolus vulgaris L., raw shelled peanut, Arachis hypogaea L., mature seeds of soybean and fruits (berries) of privet, Ligustrum lucidum Ait. (Oleaceae). This mixture of foods provided is routinely used to rear stink bugs in the laboratory (Silva and Panizzi, 2007). Boxes were kept in a walk-in chamber at $25 \pm 1{ }^{\circ} \mathrm{C}$ temperature, $65 \pm 5 \% \mathrm{RH}$ and a photoperiod of $14: 10 \mathrm{~h}(\mathrm{~L}: \mathrm{D})$.

Bugs were checked every other day and the food was replaced when necessary. The colony was replenished approximately twice per month with the addition of field-collected adults and nymphs. Adults from the laboratory colony were used to infest the cages, using an approximate sex ratio of 1 female to 1 male.

\subsection{Studies conducted in the screenhouse}

From September to November 2013, a screenhouse study was conducted at the Embrapa Wheat Research Unit in Passo Fundo, RS state, Brazil. Wheat seeds of cv. BRS Parrudo were seeded in pots $(18 \times 22 \mathrm{~cm})$. Each pot contained one plant, which was covered with a net supported by a metal frame. Plants were infested at two different phenological stages of development according to scale proposed by Feekes \& Large (Large, 1954): vegetative period (stage 3 - V3) with plants ca. $25 \mathrm{~cm}$ high, and during the reproductive period (stage $10-\mathrm{R} 10$ ), when plants were starting to develop ear heads inside the stems (booting).

Each plant was infested with 1, 2 or 4 stink bugs; control pots were kept uninfested. Each infestation level and control pot was replicated four times in a completely randomized design and repeated twice. The infestation period lasted 16 days, for each of the plant stages tested. At the end of the infestation period for the vegetative stage, the number of leaves showing damage (i.e., stink bug feeding signs with tissue necrosis, and filiform dead tissue at their tips) was recorded. This last procedure was done only in the second repetition. After the infestation period, the bugs were removed and the plants allowed to mature. At maturation, plants were harvested and taken to the laboratory. Plant height, ear head length, and grain yield were then evaluated.

\subsection{Studies conducted in the field (2013 and 2014)}

For field trials, seeds of cv. BRS Parrudo were planted at the Embrapa Wheat Field Experiment Station in rows spaced $20 \mathrm{~cm}$ apart. The soil was fertilized with NPK (5-25-25) with $200 \mathrm{~kg} \mathrm{ha}^{-1}$ and the herbicide Hussar ${ }^{\circledR}$ (a.i. iodosulfuron-methyl-sodium -60\%) $6 \mathrm{~g}$ a.i. ha ${ }^{-1}$ was used to kill the weeds prior to the establishment of the wheat field. From June to November 2013 and 2014, field cages $(1.0 \times 1.0 \times 1.5 \mathrm{~m})$ were set over wheat plants. In 2013 , plants were infested at two different phenological stages of development according to Feekes \& Large scale (Large, 1954): the vegetative stage (stage 3 - V3) with plants ca. $25 \mathrm{~cm}$ high, and during the reproductive stage (stage 11.1 - R11.1), when the grains in the ear heads were developing (milky grain stage). In 2014, plants were infested at the same phenological stages tested in 2013; but an additional stage, the reproductive stage R10 (booting) was also evaluated.

When plants reached ca. $15 \mathrm{~cm}$, plant population in each cage $\left(1 \mathrm{~m}^{2}\right)$ was thinned to 50 plants. At the appropriate developmental stage, plants in the cages were infested with $0,2,4$, and 8 stink bugs and arranged in a randomized block design. Each infestation level was replicated four times. The infestation period lasted 18 days for each of the plant stages tested. Survival of the bug was assessed per week. When dead bugs were found in the cage, they were replaced.

After the infestation period, bugs were eliminated from the cages with the application of insecticide [Acefato $\operatorname{Nortox}^{\circledR}$ (a.i. Acephate) $750 \mathrm{~g}$ a.i. ha ${ }^{-1}$ ]. At maturation the cages were removed, plants were harvested and taken to the laboratory. For each cage, the grain yield ha ${ }^{-1}$ was calculated.

In the second year, we examined the seed quality from the plants infested with $D$. furcatus (seeds from the first year were damaged by excess humidity during storage which prevented the analysis). Seeds from plants infested during the milky grain stage were placed in germination paper Germitex ${ }^{\circledR}$ with moisture and placed in an environmental chamber at $0.5{ }^{\circ} \mathrm{C}$ for 5 days, and then placed in another chamber at $20^{\circ} \mathrm{C}$ and $12 \mathrm{~h}$ light photoperiod for another 5 days. After this period, 100 seeds per replicate were analyzed for germination and the number of normal seedlings, i.e., seedlings without any sign of damage in leaves and roots (MAPA, 2009) were counted.

\subsection{Statistical analysis}

Data from the screenhouse test (plant height, ear head length, leaf damage signs, and grain yield) and field cage tests (grain yield and seed quality) were submitted to analysis of variance (ANOVA), and means were compared using the Tukey test $(P<0.05)$. Plant height and ear head length were averaged across tillers for each plant (experimental unit) prior to ANOVA. All statistics were performed using the statistics program $R$ (version 3.0.3) ( $R$ Development Core Team, 2014). Data of grain yield were expressed in $\mathrm{kg} \mathrm{ha}^{-1}$, considering 300,000 plants ha ${ }^{-1}$, according to technical recommendation (Fundação Meridional, 2014).

\section{Results}

\subsection{Studies conducted in the screenhouse}

When plants were infested during the vegetative stage for 16 days, plant height $(\mathrm{cm})(\mathrm{F}=7.9 ; \mathrm{df}=3,28 ; P<0.0005)$ and ear head length $(\mathrm{cm})(\mathrm{F}=9.7 ; \mathrm{df}=3,28 ; P<0.0001)$ were significantly reduced by stink bug feeding, although there were no significant differences among stink bug numbers (Fig. 1A,C). Stink bug infestation during booting also significantly reduced plant height $(\mathrm{F}=15.3 ; \mathrm{df}=3,28 ; P<0.0001)$ and ear head length $(\mathrm{F}=7.0$; df $=3,28 ; \mathrm{P}<0.0011)$ compared to the uninfested plants (Fig. 1B,D).

The number of leaves showing stink bug damage (tissue necrosis at the feeding site) during the vegetative stage was significantly $(\mathrm{F}=14.8 ; \mathrm{df}=3,12 ; P<0.0002)$ greater with 4 stink bugs per plant compared to those infested with 1 or 0 stink bugs per plant (Fig. 2). There were no differences in leaf damage between plants infested with 1 or 2 bugs per plant. Uninfested plants (controls) showed no signs of damage and were significantly different from plants with 2 or 4 bugs per plant. Statistically similar results were observed for the stink bug damage characterized as leaves with filiform dead tissue at their tips $(\mathrm{F}=11.7 ; \mathrm{df}=3,12 ; P<0.0007)$ (Fig. 2).

Despite the very high levels of infestation (up to 4 bugs per plant), no significant $(\mathrm{F}=1.16 ; \mathrm{df}=3,28 ; P<0.3430$ ) reduction in grain yield was observed for plants infested during the vegetative 

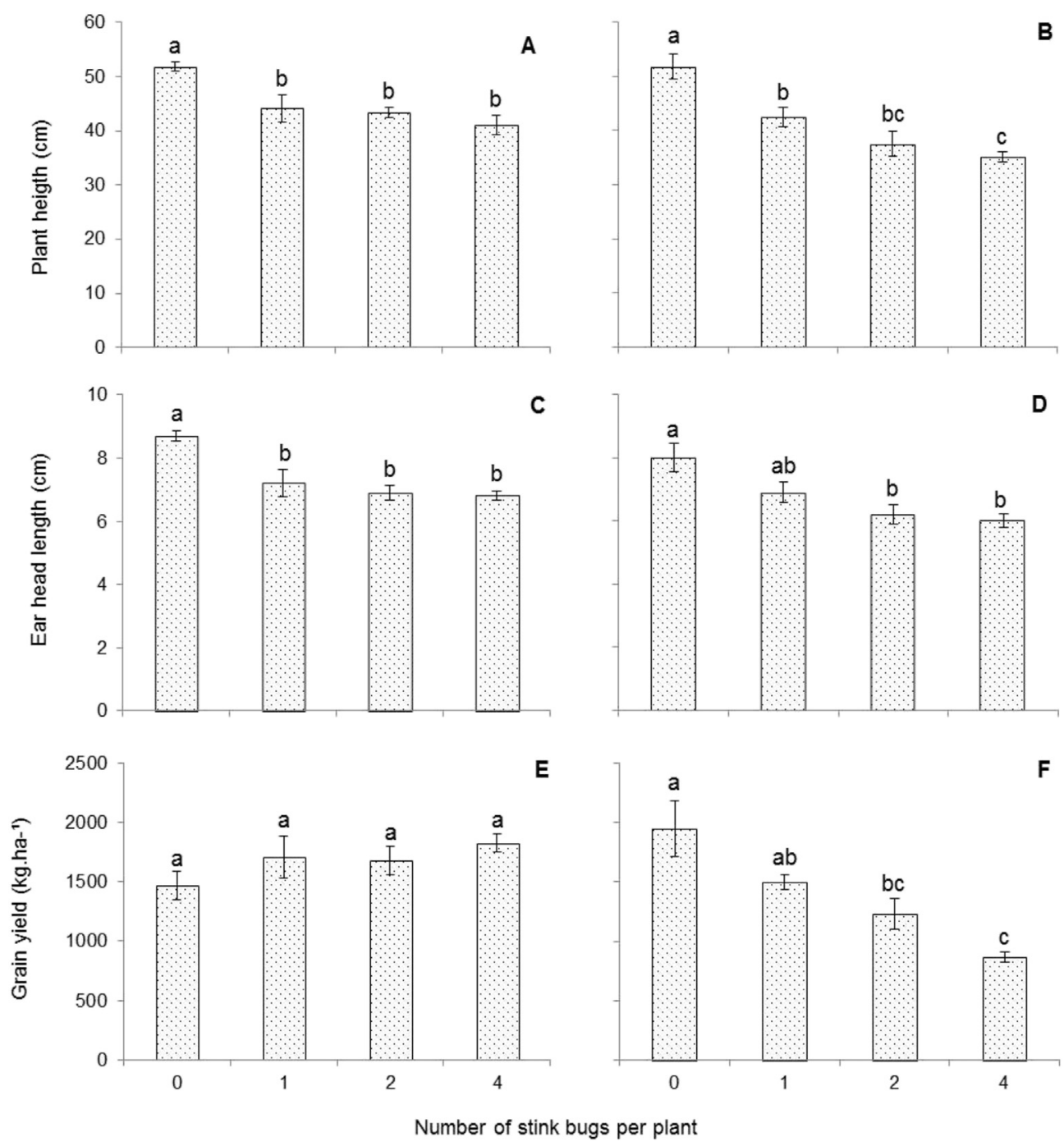

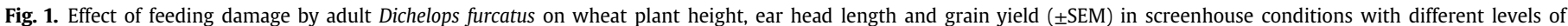
infestation during the vegetative stage $(A, C, E)$ and booting stage $(B, D, F)$. Columns with the same letter do not differ significantly $(P<0.05)$ using the Tukey test.

stage (Fig. 1E). However, during booting stage, the grain yield was significantly $(\mathrm{F}=10.5 ; \mathrm{df}=3,28 ; P<0.0001)$ reduced by 2 and 4 bugs per plant. Grain yield with 1 bug per plant did not differ from that in the uninfested plants (Fig. 1F). Infestations during the booting caused completely discolored (pale yellow) ear heads when the plants were still green. Also, some ear heads were smaller and abnormally developed.

\subsection{Field studies}

During the first year of the field study (2013), the mean grain yield was not significantly $(\mathrm{F}=1.05 ; \mathrm{df}=3,12 ; P=0.407)$ reduced with up to 8 bugs per $\mathrm{m}^{2}$ during the vegetative stage (mean \pm SEM grain yield in $\mathrm{kg} \mathrm{ha}^{-1}$ with $0-8$ bugs per $\mathrm{m}^{2}$ varied from $4386 \pm 141$ to $3874 \pm 513$ ). Stink bug infestations of up to 8 bugs per $\mathrm{m}^{2}$ during the milky grain stage did not significantly $(\mathrm{F}=0.82$; $\mathrm{df}=3,12$; $P=0.506)$ affect the mean grain yield $(4535 \pm 462$ to $4969 \pm 283)$. During the second year (2014), grain yield was not significantly reduced by number of bugs in the vegetative $(\mathrm{F}=0.395$; $\mathrm{df}=3,12$; $P=0.759)(3504 \pm 120$ to $3472 \pm 364)$, booting $(\mathrm{F}=0.080 ; \mathrm{df}=3$, $12 ; P=0.969)(3004 \pm 312$ to $2968 \pm 324)$, and milky grain stages $(\mathrm{F}=0.667 ; \mathrm{df}=3,12 ; P=0.588)(3356 \pm 212$ to $3100 \pm 308)$.
Feeding damage by adults of $D$. furcatus at the milky grain stage resulted in a significantly decreased proportion of normally developing seedlings $(\mathrm{F}=4.02 ; \mathrm{df}=3,12 ; P<0.009)$ with 8 bugs per $\mathrm{m}^{2}$ (Fig. 3).

\section{Discussion}

Results of these screenhouse and field studies demonstrated that the green belly stink bug can cause significant damage to grain yield and seed quality of wheat, depending on the infestation level and the phenological stage of plant development. The fact that no significant reduction in grain yield occurred during the vegetative stage, even with very high level of infestation ( 4 bugs per plant in the screenhouse and 8 bugs per $\mathrm{m}^{2}$ in the field), suggests that during this period wheat plants can recover from the feeding damage. Therefore, our results suggest that there is no need to control $D$. furcatus during the vegetative stage. The feeding activity causes tissue necrosis on leaves and sometimes results in filiform dead tissue at the leaf tips (Fig. 4 A,B). This type of damage is similar to that caused by another species of pentatomid, $D$. melacanthus (Chocorosqui and Panizzi, 2004) to wheat leaves. This damage resulted from high infestations of bugs per plant in the 

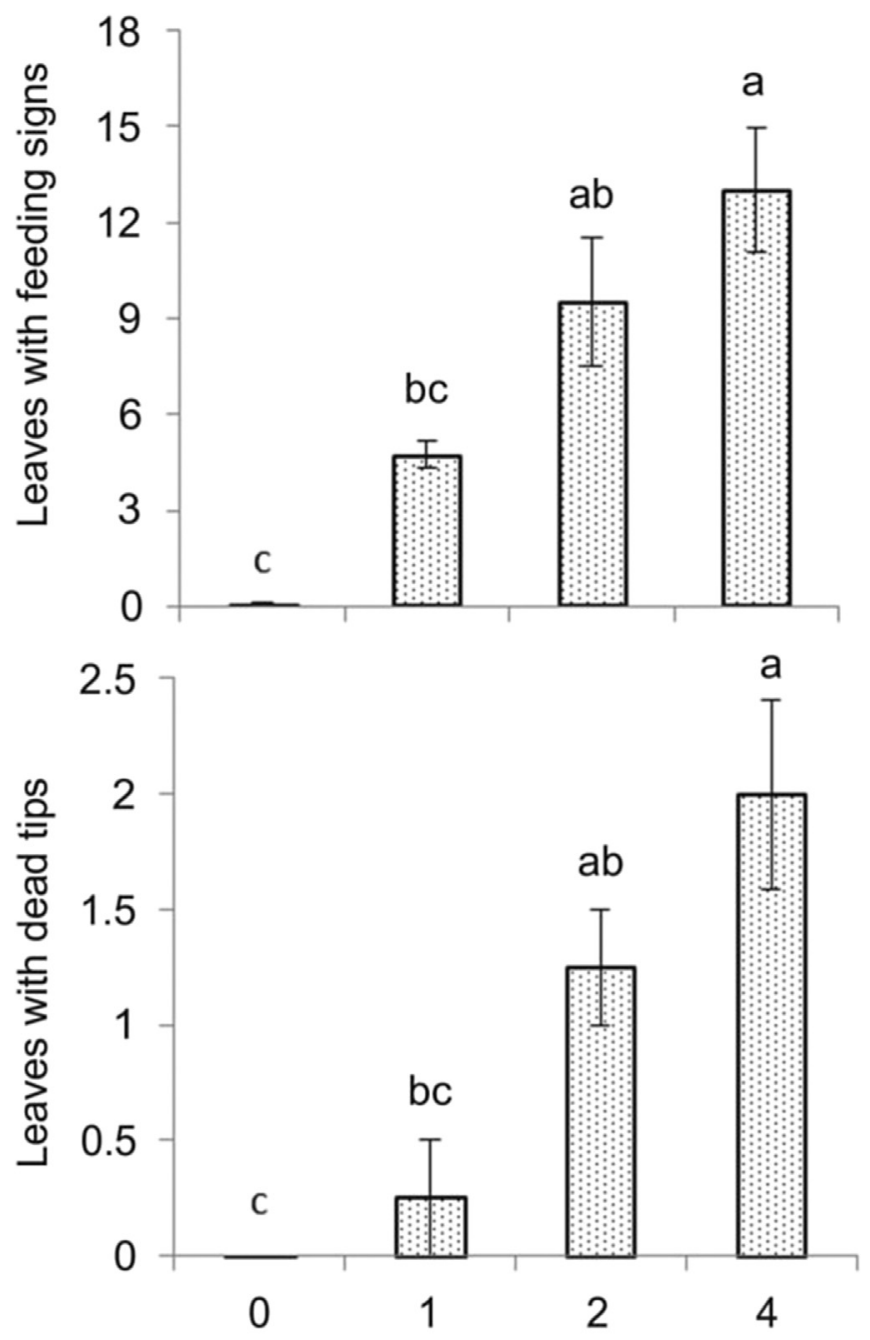

Number of stink bug per plant

Fig. 2. Mean ( \pm SEM) number of wheat leaves with signs of feeding and with dead tips caused by adult Dichelops furcatus during the vegetative stage under screenhouse conditions. Columns with the same letter do not differ significantly $(P<0.05)$ using the Tukey test.

screenhouse, and was seldom observed in the field cages. Additional observations in commercial wheat field suggest that damage to leaves and seedlings require high levels of Dichelops spp. infestations, which can occur due to their aggregated spatial distribution in wheat fields (Chocorosqui and Panizzi, 2004).

The fact that during booting significant reduction in grain yield occurred with 2 or more bugs per plant in one of the four trials suggests that this is the most susceptible stage to feeding by these bugs. The damage caused completely discolored and deformed ear heads (Fig. 4 C). This symptom, described by Pereira et al. (2013), is sometime observed in the field and we have demonstrated for the first time that these symptoms occur when feeding damage by the bugs occurs during the booting stage. However, because no significant reduction in seed yield and quality occurred even with 4 bugs per $\mathrm{m}^{2}$ in the field cages, control measures should likely not be taken until the number of bugs in the field exceeds this level.

Our results demonstrated that, although no reduction in grain yield occurred, the decreased number of normal seedlings with 8 bugs per $\mathrm{m}^{2}$ during the milky grain suggests that stink bug control might be needed at this time. However, one should notice that this

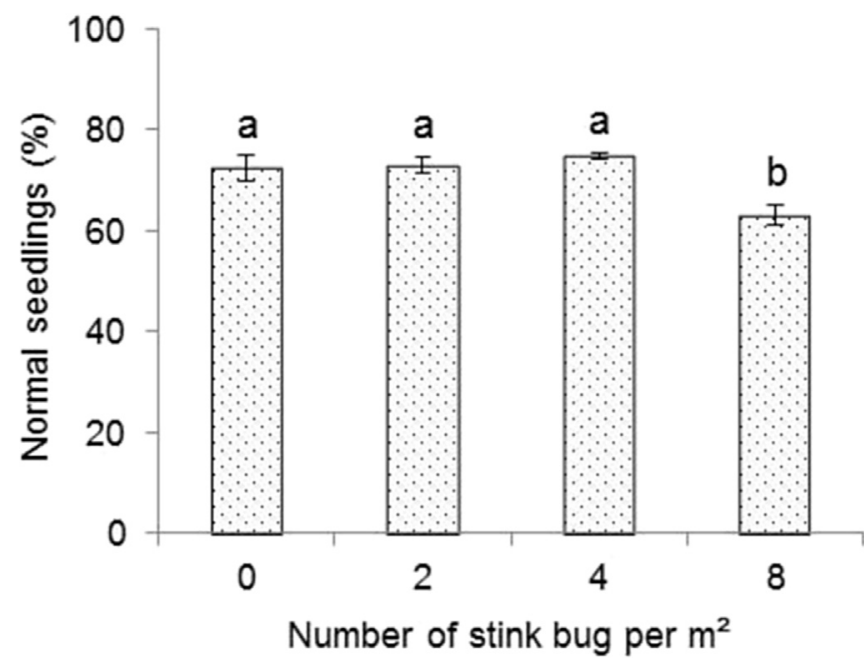

Fig. 3. Effect of the feeding damage by different numbers of adults of Dichelops furcatus on wheat seed quality expressed as percentage of normal seedlings $( \pm$ SEM) in field cages during the milky grain stage. Columns with by the same letter do not differ significantly $(P<0.05)$ using the Tukey test.

level of infestation is considered very high, and seldom is achieved by natural populations in the field (A. R. Panizzi, personal observation). Studies conducted in screenhouse with another pentatomid that occurs on wheat in Brazil, Thyanta perditor (F.), found that a significant reduction in grain yield was observed only with a very high level of infestation (i.e., 4 bugs per ear head) during 24 days from the beginning of grain formation (Ferreira and Silveira, 1991).

In general, in the neotropics, pentatomids are not considered regular pests of wheat, which is not the case in other parts of the world, such as in the Orient, where several species of pentatomids of the genus Aelia and scutellerids of the genus Eurygaster are regarded as major pests (Javahery, 1995; Javahery et al., 2000). These bugs can cause the primary shoot of the central leaf to wither, and attack to the lower part of the internode may cause plant breakage; ear heads may be damaged while still in the booting stage and after heading the spike above the puncture withers (Stamenković, 1976). This injury is, in general, similar to that caused by $D$. furcatus here reported and illustrated.

In Brazil, pentatomids D. furcatus, T. perditor (Panizzi and Herzog, 1984; Ferreira and Silveira, 1991) and Nezara viridula (L.) (Maia, 1973) have been reported to feed on wheat. However, none of the three species seems to reproduce with great success on wheat in the field, and eggs and nymphs are seldom found on this plant. D. furcatus is more often associated with soybean where it reproduces more successfully than on wheat (Rizzo, 1976; Link and Grazia, 1987; Ribeiro et al., 2009; Chiaradia et al., 2011). T. perditor, despite being called in Brazil 'the wheat stink bug' (Pereira et al., 2013 ) is not frequently found on the crop. Its association with wheat and soybean is probably due to its feeding and reproducing on its preferred host plant, the weed Bidens pilosa L., which is common in wheat and soybean fields (Panizzi and Herzog, 1984). $N$. viridula, which is extremely polyphagous, is not reported as reproducing on wheat in the neotropics (Lopes et al., 1974; Ferreira and Panizzi, 1982) despite the report of its occurrence as nymphs and adults, and causing damage to the crop (Maia, 1973).

The general low levels damage of $D$. furcatus on wheat may be explained by the following three factors: first, the bug does not thrive when feeding on wheat, and reproduction does not occur or happens only occasionally (Link and Grazia, 1987). Therefore, the wheat plant is not a primary host, but an associated plant, resulting in minor damage. Second, the cultivar used BRS Parrudo is known 

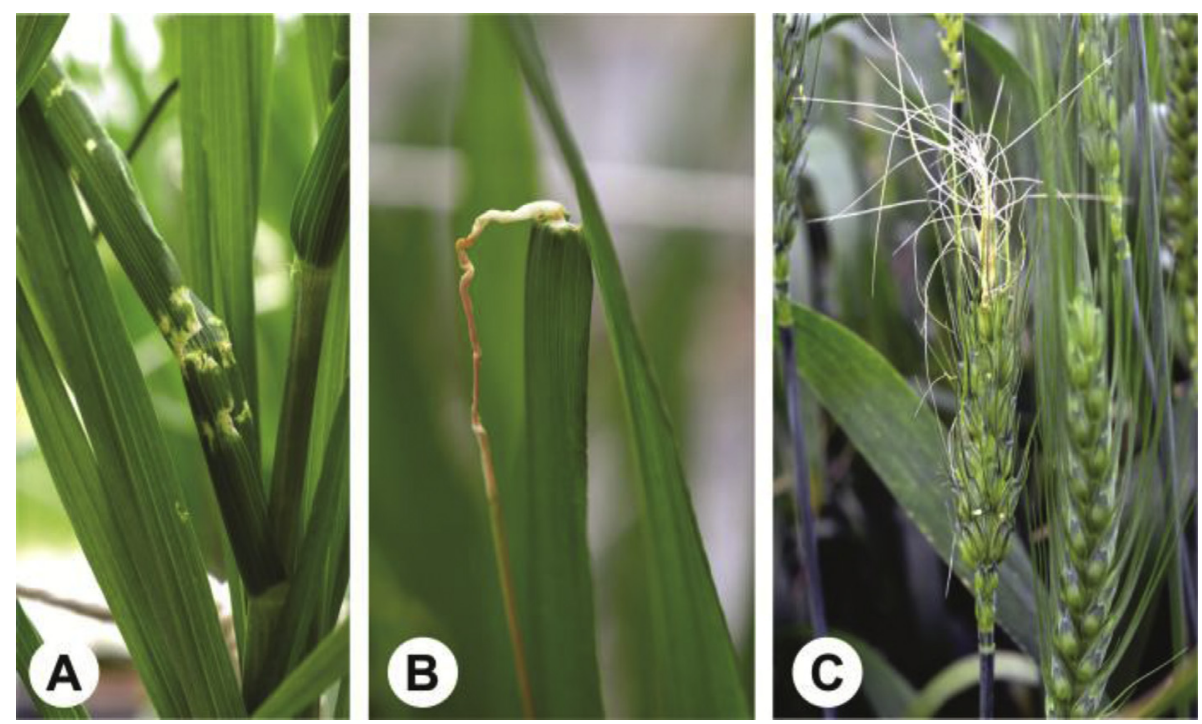

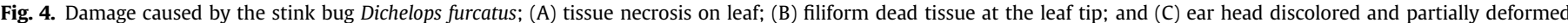
(photos by P.R.V.S. Pereira)

to have traits such as stems resistant to lodging (solid stems) (Caierão et al., 2014) that might confer resistance to the stink bug damage, since $D$. furcatus feeds mostly on the stems. Solidstemmed wheat cultivars, although not reported to be resistant to stink bug attack, are traditionally known to confer resistance to the wheat stem sawfly, Cephus cinctus Norton (Weiss and Morrill, 1992). Damage by $D$. furcatus observed on other commercially grown cultivars in Brazil might be greater compared with BRS Parrudo. However, this can be only speculated, because no data are available on the damage by $D$. furcatus to other commercial cultivars. Third, the relatively low temperatures in the field might have inactivated the feeding activity of the bugs. For instance, in 2013, the mean temperature from June to October varied from 12.9 to $18.4{ }^{\circ} \mathrm{C}$; in 2014 these values varied from 13.7 to $18.3^{\circ} \mathrm{C}$ (source: www.cnpt.embrapa.br/pesquisa/agromet/app/principal/index. php). We have observed that these temperature ranges (below $20{ }^{\circ} \mathrm{C}$ ) caused bugs to remain mostly inactive, which probably reduced their feeding activity. Not much data are found in the literature on the effect of temperature on the feeding activity of Neotropical pentatomids. The red banded stink bug, Piezodorus guildinii (Westwood) was reported to reduce its feeding activity with temperature decrease from 25 to $20{ }^{\circ} \mathrm{C}$ in the laboratory (Zerbino et al., 2014); however, no data were found on feeding activity of stink bugs below $20^{\circ} \mathrm{C}$ in the neotropics.

In conclusion, results of these tests suggest that $D$. furcatus, despite its relative abundance in wheat fields of southern Brazil, it is not a major pest. Because numbers may continue to increase on wheat crop the pest status of this bug should continue to be evaluated.

\section{Acknowledgments}

We thank Joseph E. Eger and three anonymous reviewers for critically reading the manuscript. This research is part of a project sponsored by the National Research Council of Brazil (CNPq) grant \# 471517/2012-7 in collaboration with Embrapa. Alice Agostinetto (grant \# 471517/2012-7) and Tiago Lucini (grant \# 1561050/2013) were supported by scholarships from the CNPq and Ministry of Education (CAPES), respectively. We thank Lisonéia F. Smaniotto, Maria E.S. Moreira, Vânia Bianchin, and Taymara A. B. Bonissoni, for their help in the screenhouse, field, and laboratory activities.

\section{References}

Ávila, C.J., Duarte, M.M., 2012. Eficiência de inseticidas, aplicados nas sementes e em pulverização, no controle do percevejo barriga-verde Dichelops melacanthus (Dallas) (Hemiptera: Pentatomidae), na cultura do milho. BioAssay 7, 1-6 (in Portuguese, with abstract in English).

Caierão, E., Scheeren, P.L., Silva, M.S., Castro, R.L., 2014. History of wheat cultivars released by Embrapa in forty years of research. Crop Breed. Appl. Biotechnol. 14, 216-223.

Chiaradia, L.A., Rebonatto, A., Smaniotto, M.A., Davila, M.R.F., Nesi, C.N., 2011. Arthropods associated with soybean crops. Rev. Ciênc. Agrovet. 10, 29-36 (in Portuguese, with abstract in English).

Chocorosqui, V.R., Panizzi, A.R., 2004. Impact of cultivation systems on Dichelops melacanthus (Dallas) (Heteroptera: Pentatomidae) populations and damage and its chemical control on wheat. Neotrop. Entomol. 33, 487-492.

Ferreira, B.S.C., Panizzi, A.R., 1982. Stink bugs pests of soybean in northern Parana: abundance in relation to plant phenology and intermediate hosts (Percevejos pragas da soja no Norte do Paraná: abundância em relação à fenologia da planta e hospedeiros intermediários). In: Anais do Seminário Nacional de Pesquisa de Soja, Londrina, vol. 1, pp. 140-151.

Ferreira, E., Silveira, P.M., 1991. Grain yield losses due to Thyanta perditor (Hemiptera: Pentatomidae) in wheat (Triticum aestivum L.). An. Soc. Entomol. Bras. 20 165-171 (in Portuguese, with abstract in English).

Frota, R.T., Santos, R.S.S., 2007. Pentatomidae bugs associated with sunflower crops in the northwest of Rio Grande do Sul state and the action of Euschistus heros (Fabricius, 1794) (Hemiptera: Pentatomidae) on sunflower seeds. Biotemas 20, 65-71 (in Portuguese, with abstract in English).

Javahery, M., 1995. A Technical Review of Sunn Pests (Heteroptera: Pentatomidae) with Special Reference to Eurygaster integriceps Puton. FAO, Regional Office for the Near East, Cairo, Egypt.

Javahery, M., Schaefer, C.W., Lattin, J.D., 2000. Shield bugs, pp. 475-503. In Schaefer, C.W., Panizzi, A.R. (Eds.), Heteroptera of Economic Importance. CRC Press, Boca Raton, FL, USA, p. 828.

Large, E.C., 1954. Growth stages in cereals. Illustration of the Feekes scale. Plant Path. 3, 128-129.

Link, D., Grazia, J., 1987. Pentatomids of the central region of Rio Grande do Sul (Pentatomídeos da região central do Rio Grande do Sul). An. Soc. Entomol. Bras. 16, 115-129 (in Portuguese, with abstract in English).

Lopes, O.J., Link, D., Basso, L.V., 1974. Pentatomids of Santa Maria - preliminary list of the host-plants. Rev. Cent. Cien. Rur. 4, 317-322 (in Portuguese, with abstract in English).

Maia, N.G., 1973. Occurrence of the southern green stink bug Nezara viridula (L.) on seed heads of wheat in Rio Grande do Sul. Agron. Sulriogr. 9, 241-243 (in Portuguese, with abstract in English).

Manfredi-Coimbra, S., Silva, J.J., Chocorosqui, V.R., Panizzi, A.R., 2005. Danos do percevejo barriga-verde Dichelops melacanthus (Dallas) (Heteroptera: Pentatomidae) em trigo. Ciência Rural. 35, 1243-1247 (in Portuguese, with abstract in English).

Ministério da Agricultura, Pecuária e Abastecimento [MAPA], 2009. Rules for Seed Analysis (Regras para a Análise de Sementes). Ministério da Agricultura, 
Pecuária e Abastecimento, Brasília, DF, Brazil (in Portuguese).

Martins, G.L.M. Toscano, L.C., Tomquelski, G.V., Maruyama, W.I., 2009. Controle químico do percevejo barriga-verde Dichelops melacanthus (Hemiptera: Pentatomidae) na cultua do milho. Arq. Inst. Biol. 76, 475-478 (in Portuguese, with abstract in English).

Meridional, Fundação, 2014. Technical information on wheat and triticale. Crop season 2014 (Informações Técnicas para Trigo e Triticale. Safra 2014). In: VI Reunião da Comissão de Pesquisa de Trigo e Triticale, Londrina, PR, Brazil (in Portuguese).

Panizzi, A.R., Herzog, D.C., 1984. Biology of Thyanta perditor (Hemiptera: Pentatomidae). Ann. Entomol. Soc. Am. 77, 646-650.

Panizzi, A.R., Corrêa, B.S., Gazzoni, D.L., Oliveira, E.B., Newman, G.G. Turnipseed, S.G., 1977. Insects of Soybean in Brazil. Bol. Téc. Número 1. Embrapa, Londrina, PR, Brazil (in Portuguese).

Pereira, P.R.V.S., Salvadori, J.R., Lau, D., Marsaro Jr., A.L., Panizzi, A.R., 2013. Wheat: Integrated Management of Pests. Doc. Num. 113. Embrapa, Passo Fundo, RS, Brazil (in Portuguese).

R Development Core Team, 2014. R: a Language and Environment for Statistical Computing. R Foundation for Statistical Computing, Vienna, Austria.

Ribeiro, A., Castiglioni, E., Silva, H., Bartaburu, S., 2009. Floating population of stink bugs (Hemiptera: Pentatomidae) on soybean (Glycine max) and lotus (Lotus corniculatus) (Fluctuaciones de poblaciones de pentatómidos (Hemiptera: Pentatomidae) en soja (Glycine max) y lotus (Lotus corniculatus)). Bol. Sanid. Veg. Plagas 35, 429-438 (in Spanish).

Rizzo, H.F.E., 1976. Hemipterans Pests of Crops (Hemípteros de Interés Agrícola). Editora Hemisferio Sur, Buenos Aires, Argentina (in Spanish).

Roza-Gomes, M.F., Salvadori, J.R., Pereira, P.R.V.S., Panizzi, A.R., 2011. Injuries of four species of stink bugs to corn seedlings. Cienc. Rural. 41, 1115-1119 (in Portuguese, with abstract in English).

Silva, F.A.C., Panizzi, A.R., 2007. Cotton balls as an oviposition substrate for laboratory rearing of phytophagous stink bugs (Heteroptera: Pentatomidae). Ann. Entomol. Soc. Am. 100, 745-748.

Smaniotto, L.F., Panizzi, A.R., 2015. Interactions of selected species of stink bugs (Hemiptera: Heteroptera: Pentatomidae) from leguminous crops with plants in the neotropics. Fla. Entomol. 98, 7-17.

Stamenković, S., 1976. Vidovi oštećenja od žitnih stenica. Zas. Bilja 27, 335-348 (in Serbian, with abstract in English).

Weiss, M.J., Morrill, W.L., 1992. Wheat stem sawfly (Hymenoptera: Cephidae) revisited. Am. Entomol. 38, 241-245.

Zerbino, M.S., Altier, N., Panizzi, A.R., 2014. Phenological and physiological changes in adult Piezodorus guildinii (Heteroptera: Pentatomidae) due to variation in photoperiod and temperature. Fla. Entomol. 97, 734-743. 